\title{
La catechesi: annunci e testimonianze fra incontro e dialogo
}

\author{
Catechesis: \\ announcing and bearing witness between meeting \\ and dialogue
}

Giuseppina Battista

\section{Riassunto}

Nell'ambito della pastorale, la catechesi è stata definita quell'azione ecclesiale che conduce le comunità cristiane e i singoli fedeli alla maturità nella fede, e configurata come itinerario di sequela di Cristo. Per accompagnare i battezzati in questo cammino di maturazione e di crescita nell'amore di Dio, i catechisti devono agire nel rispetto del principio della fedeltà a Dio e all'uomo. Uno stile teologico-educativo che privilegia la dimensione dell'ascolto: della parola di Dio e delle parole 'umane'. La missione educativa affidata da Gesù, "andate e fate discepoli tutti i popoli" (cf. Mt 28, 18-20) esige dagli educatori la disponibilità ad incontrare l'altro, ad accoglierlo e a dialogare con lui, seguendo l'esempio di Gesù nel Vangelo e di celebri educatori nella storia. Di fronte al fenomeno del pluralismo, diventato il nostro nuovo ambiente di vita, la catechesi deve proporre nuovi paradigmi di formazione cristiana, in dialogo con la cultura del tempo, per formare dei discepoli di Cristo, capaci di esseri costruttori di pace e di dialogo tra le differenti fedi religiose, come testimonianza dell'amore di Dio.

Parole chiave: accoglienza; ascolto; dialogo; fede. 


\begin{abstract}
In a pastoral context, Catechesis has been defined as the ecclesiastical action leading Christian communities and the faithful to fullness of faith, and it has been designed as a pathway to becoming followers of Christ. In order to accompany the baptized along this path toward maturity and growth in God's love, catechists must act with due respect for the principles of fidelity to Christ and men. This requires a theological-educational style which stresses the dimensions of listening to both God's word and "human" words. The formative mission which was entrusted by Jesus: "go and teach all the nations" (cf. Matt 28, 18-20) requires educators to be ready to meet others, to welcome them and to converse with them, following Jesus' example in the Gospel and that of other well known educators throughout our history. Challenged by the phenomenon of pluralism, which has become the background to everyday life, catechesis must offer a new model of Christian formation, and foster dialogue with contemporary culture. It should strive to shape disciples of Christ, able to bear witness to God's love by promoting peace and interacting with different religious traditions.
\end{abstract}

Keywords: welcoming; listening; dialogue; faith. 